\title{
Abundance, breeding and food of the Little Blue Heron Egretta caerulea (Aves, Ardeidae) in the Patos Lagoon estuary, a recently colonized area in southern Brazil
}

\author{
Dimas Gianuca ${ }^{1}$, Andros T. Gianuca ${ }^{2}$ \& Carolus M. Vooren ${ }^{3}$
}

\author{
1. Programa de Pós-Graduação em Oceanografia Biológica, Instituto de Oceanografia, Universidade Federal do Rio Grande (FURG), Caixa Postal 474, Avenida Itália km 8, 96201-900, \\ Rio Grande, RS, Brazil. (dmsgianuca@hotmail.com) \\ 2. Programa de Pós-Graduação em Ecologia, Instituto de Biociências, Universidade Federal do Rio Grande do Sul (UFRGS), Av. Bento Gonçalves, 9500, 91501-970, Porto Alegre, RS, Brazil. \\ (agianuca@hotmail.com) \\ 3. Instituto de Oceanografia, Universidade Federal do Rio Grande (FURG), Caixa Postal 474, Avenida Itália km 8, 96201-900, Rio Grande, RS, Brazil. (cmvooren@gmail.com)
}

\begin{abstract}
We document the expansion of the breeding distribution of the Little Blue Heron Egretta caerulea (Linnaeus, 1758) to $850 \mathrm{~km}$ beyond its previous southern limit in South America. In addition we present data on abundance, breeding biology and food of the species in the Patos Lagoon estuary, the area which the species recently colonized. The maximum abundance recorded in the breeding colony and in a nocturnal roosting site was 53 and 49 individuals respectively. Nesting occurred from September to March. Birds nested in a mixed breeding colony together with about 3,000 breeding pairs of seven other species of Pelecaniformes, in a swampy forest near the margin of the estuary. Five nests were between 1.5 and $4.3 \mathrm{~m}$ from the ground, on the shrub Daphnopsis racemosa (Thymelaeaceae), on the trees Sebastiana brasiliensis (Euphorbiaceae) and Mimosa bimucronata (Leguminosae), or on the bamboo Bambusa sp. (Poaceae). Four nests produced two fledglings each, while one nest was abandoned. Of 13 grouped samples of food regurgitated by five nestlings, Pink Shrimp Farfantepenaeus paulensis (PerezFarfante, 1967) constituted $70 \%$ in mass, while total length of ingested fishes and shrimps varied mostly between 20 and $50 \mathrm{~mm}$. Estuarine prey items represented $99 \%$ of the total food mass. The recent southward expansion of the breeding range of the Little Blue Heron in South America may be a response to climate warming of the Patos Lagoon estuary. Degradation of estuaries in the southwestern Atlantic may also be forcing the birds to breed in areas outside previous geographical range.
\end{abstract}

KEYWORDS. Climate change, herons, reproduction, Rio Grande do Sul, range expansion.

RESUMO. Abundância, reprodução e alimentação da garça-azul Egretta caerulea no estuário da Lagoa dos Patos, uma área recentemente colonizada no sul do Brasil. No presente trabalho é documentada a expansão da distribuição reprodutiva da garça-azul Egretta caerulea (Linnaeus, 1758) $850 \mathrm{~km}$ para o sul das colônias mais austrais previamente conhecidas. Adicionalmente, são apresentadas informações sobre abundância, reprodução e alimentação da espécie no estuário da Lagos dos Patos, região recentemente colonizada no extremo sul do Brasil. As garças-azuis nidificaram em uma colônia multiespecífica localizada em uma mata paludosa às margens do estuário, contendo outras sete espécies de Pelecaniformes, totalizando cerca de 3.000 pares reprodutivos. O período reprodutivo se estendeu de setembro até fins de março, e as maiores abundâncias registradas na colônia e no dormitório foram 53 e 49 indivíduos, respectivamente. Foram encontrados cinco ninhos, construídos sobre árvores Sebastiana brasiliensis (Euphorbiaceae) ou Mimosa bimucronata (Leguminosae), arbustos Daphnopsis racemosa (Thymelaeaceae), ou bambus Bambusa sp. (Poaceae), em alturas entre 1,5 e 4,3 m acima do solo. Quatro ninhos produziram dois filhotes cada, e um foi abandonado. Em uma análise preliminar da dieta, baseada em 13 amostras de alimento regurgitado de cinco filhotes, verificou-se que camarões-rosa Farfantepenaeus paulensis (Perez-Farfante, 1967) corresponderam a 70\% das presas consumidas, e os itens alimentares de origem estuarina constituíram $99 \%$ da biomassa ingerida. Todos os peixes e a maioria dos camarões consumidos possuíam comprimento total entre 20 e $50 \mathrm{~mm}$. A recente expansão da distribuição reprodutiva da garça-azul em direção ao sul pode ter sido favorecida pelo aquecimento climático observado na região do estuário da Lagoa dos Patos, e influenciado pela degradação dos estuários no Atlântico sudoeste nas últimas décadas, levando as aves a colonizarem áreas fora da sua distribuição habitual.

PAVAVRAS-CHAVE. Mudança climática, garças, reprodução, Rio Grande do Sul, expansão de distribuição.

The Little Blue Heron Egretta caerulea (Linnaeus, 1758 ) is a New World ardeid which inhabits mostly coastal wetlands. Its known breeding range on the Atlantic coast extends from south Maine (USA) to the state of São Paulo (Brazil), and on the Pacific coast from Arizona (USA) to Lima (Peru) (Kushlan \& HANCOCK, 2005). In North America the Little Blue Heron also nests inland (e.g. Along the Mississippi River Valley), and the type of vegetation appears to be relatively unimportant for this species (KUSHLAN \& HANCOCK, 2005). However, in South America the Little Blue Heron occurs inland only as a vagrant, and its geographical range of regular occurrence and breeding is mainly associated with the coastal distribution of the Rizophora, Avicennia and Laguncularia mangrove forests (Olmos \& Silva e Silva, 2002; Kushlan \& HaNCOCK, 2005).

Low winter temperatures preclude mangrove growth in the state of Rio Grande do Sul (CINTRÓNMolero \& Schaeffer-Novelli, 1992), where the Little
Blue Heron was first noticed in 1983 (Voss, 1984) and has since been considered a vagrant species, just as in Uruguay and Argentina (NARosky \& Yzurieta, 1993). The first documented (photographic) record of the Little Blue Heron in the state was in 2002 (Moнr, 2003).

The occasional presence of the species in or near the Patos Lagoon estuary, in Rio Grande do Sul, has been noted from 1991 to 2003 (MAURícIo \& DiAs, 1996, 2000; Vотто et al., 2006). However, after 2005 the Little Blue Heron has been observed regularly on shores and islands of the estuary, including on mixed-species roosting and breeding sites (GianUCA et al., 2008). These reports suggest that in less than 10 years the Little Blue Heron has become a common species in the Patos Lagoon estuary. However, although the presence of the species has been observed in a mixed-species breeding colony of herons on the estuarine Marinheiros Island, the actual breeding of the Little Blue Heron in the Patos Lagoon estuary has not yet been reported. 
This paper documents the breeding of Little Blue Heron in the Patos Lagoon estuary, at latitude $32^{\circ} \mathrm{S}$, thus extending the known breeding range of the species $850 \mathrm{~km}$ beyond its previous southern breeding limit, at latitude $23^{\circ} \mathrm{S}$, in mangrove forests on the coast of the state of São Paulo (Olmos \& Silva e Silva, 2002). Data are also presented on the abundance of the species on its breeding and nocturnal roosting sites, and on its breeding biology and food in the Patos Lagoon estuary.

\section{MATERIAL AND METHODS}

Study area. The Patos Lagoon estuary (31 ${ }^{\circ} 58^{\prime} 03^{\prime \prime}$; $52^{\circ} 07^{\prime} 20^{\prime \prime} \mathrm{W}$ ) (Fig. 1) covers an area of $971 \mathrm{~km}^{2}$ and connects to the ocean through a channel which is 0.5 to $3 \mathrm{~km}$ wide, $20 \mathrm{~km}$ long, and $18 \mathrm{~m}$ deep (Asmus, 1997). The amplitude of the astronomical tides is about 0.5 $\mathrm{m}$, upon which large variations of salinity and water level are superimposed by variations of rainfall and of intensity and direction of wind (COSTA et al., 1988). Salt marshes cover $70 \mathrm{~km}^{2}$ of the estuary (COSTA, 1997), and freshwater wetlands occur in adjacent areas (ISACCH et al., 2006). In the permanently flooded estuarine areas there are beds of the seagrass Ruppia maritima (Potamogetonaceae) and floating patches of macroalgae (SeEliger, 1997a,b). Mudflats with abundant benthic invertebrates are exposed during low tides (Bemvenuti, 1997).

The Marinheiros Island has an area of $40 \mathrm{~km}^{2}$ and is situated in the central portion of the estuary at $32^{\circ} 00^{\prime} \mathrm{S}, 52^{\circ} 09^{\prime} \mathrm{W}$. The island has a peripheral zone of low-lying soil which is kept humid by constant freshwater seepage out of the dune barrier that separates the peripheral lands from the higher sandy interior of the island. The original forest cover of the humid peripheral zone of the island has been cleared, and that zone is now mostly occupied by numerous small farms which produce vegetables and fruits, but abandoned farmlands are covered by secondary forest growth. Barren areas of sandy soil occupy the interior of the island, where there are freshwater swamps and plantations of the pine Pinus elliottii (Pinaceae).

In 2007/2008 breeding season, Little Blue Herons were observed in the mixed-species breeding colony situated on the southwestern margin of the island $\left(32^{\circ} 01^{\prime} 25^{\prime \prime} \mathrm{S} ; 52^{\circ} 09^{\prime} 13^{\prime \prime} \mathrm{W}\right)$, the only such colony known in the Patos Lagoon estuary (GIANUCA et al., 2008). Besides the Little Blue Heron, about 3,000 pairs of other seven species breed there, namely Great Egret Ardea alba (Linnaeus, 1758), Cocoi Heron Ardea cocoi (Linnaeus, 1766), Snowy Egret Egretta thula (Molina, 1782), Cattle Egret Bubulcus ibis (Linnaeus, 1758), Black-crowned Night Heron Nycticorax nyctocorax (Linnaeus, 1758), Yellow-crowned Night Heron Nyctanassa violacea (Linnaeus, 1758), and Roseate Spoonbill Platalea ajaja (Linnaeus, 1758). The breeding colony occupies a dense freshwater swampy forest. The main species of shrubs and trees in the area Sebastiana brasiliensis (Euphorbiaceae), Sapium glandulosum (Euphorbiaceae), Erythrina crista-galli (Fabaceae), Schinus terebinthifolius (Anacardiaceae), Salix humboldtiana (Salicaceae), and Ficus cestrifolia (Moraceae), and there are patches of the tall bamboo Bambusa sp. The area of the colony is approximately $150 \mathrm{~m} \times 100 \mathrm{~m}$ and is situated parallel to the shore of the estuary, separated from the estuarine waters by a $50 \mathrm{~m}$ wide zone of the sedge Scirpus giganteus (Cyperaceae).

On Tamandaré Square, in de centre of the city of Rio Grande and at $6 \mathrm{~km}$ from the Marinheiros Island colony, there is a public park within which a system of artificial ponds and channels forms a small island with approximately $90 \mathrm{~m} \times 50 \mathrm{~m}$. This island is covered by trees and clumps of tall bamboo. Little Blue Herons roost regularly in this vegetation during the night, together with Snowy and Cattle Egrets (Gianuca et al., 2008). In the present paper this nocturnal roosting site is named the "Tamandare roost".

Field work. From August 2008 to August 2009, monthly censuses of Little Blue Herons were conducted at sunset at the Tamandaré roost and at the breeding colony on Marinheiros Island, except in December 2008. At the colony on Marinheiros Island, the censuses were conducted on the top of a $15 \mathrm{~m}$ high dune at $150 \mathrm{~m}$ from the center of the colony, using $12 \times 50$ binoculars and a 10-25 x $60 \mathrm{~mm}$ spotting-scope. At the Tamandaré roost the censuses were carried out with the naked eye at a place on the ground at $20 \mathrm{~m}$ from the center of the roosting site.

Each census began 60 minutes before sunset and lasted 90 minutes. In the census, three categories of birds were counted separately: settled birds, arriving birds and departing birds. Settled birds were those that stood or sat on the vegetation or on nests. Arriving birds were those that flew in from afar and then settled in the colony or in the nocturnal roosting place. Departing birds were those that took off from the colony or from the roost and then flew away from it. Settled birds were counted only at the beginning of the census. After that, arriving birds and departing birds were counted during the entire census period.

During the census each heron was classified according to the plumage as adult (plumage completely blue), intermediate (plumage pied in white and blue grey) or juvenile (plumage completely white except for gray tips of remiges) (KuSHLAN \& HANCOCK, 2005). All censuses were performed by the same observer, and only on clear days without rain.

In the analysis of the counts of a census, the estimate of the total number of birds in the census area was obtained by first adding up the number of settled birds and the number of arriving birds. When the number thus obtained was greater than or equal to the number of departing birds, it was taken as the estimate of the total number of birds present in the census area. 


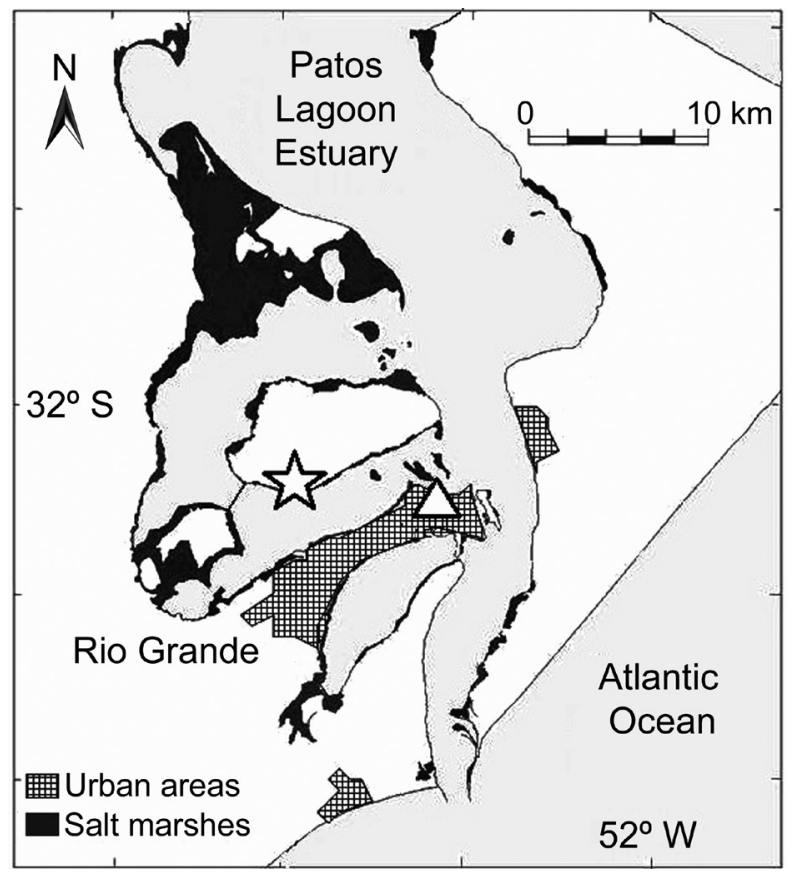

Fig. 1. Patos Lagoon estuary, with the localization of the colony of Marinheiros Island (star) and the roosting site of Tamandaré Park (triangle).

Food analysis. Thirteen samples of food regurgitated by five chicks from four different nests were collected from November 2008 to February 2009. The samples were obtained from chicks of more than one week old, evidenced by white down feathers covering all the body and emerging pinions (KUSHLAN \& HANCOCK, 2005). When the observers approached the nest, such chicks often regurgitated their stomach contents out of the nest. The regurgitated food sample was then collected from the ground. The food samples were fixed and preserved in $90 \%$ ethanol.

In the laboratory all prey items were identified to the lowest possible taxon, according to literature (FISCHER et al., 2004) and through consultation of specialists. A prey taxon present in the sample is termed a 'food item', and for each food item an individual animal in the sample is termed a 'prey' (Bugoni \& Vooren, 2004). Total length of all fish and shrimp (TL, mm) was measured, while for crabs the carapace width $(\mathrm{CW}, \mathrm{mm})$ was measured. The reconstructed mass of fishes, shrimps and crabs was estimated through regression equations of body mass as a function of TL or CW, according to D'INCAO \& Calazans (1978), Haimovici \& Velasco (2000), Vianna \& D'Incao (2006) and Alaniz (2009).

The parameters determined for each food item were its frequency of occurrence (absolute FO and relative FO, \%), its number of ingested preys (absolute and relative $\mathrm{N}$ ), its reconstructed mass (absolute and relative $\mathrm{M}$ ) and its Index of Relative Importance (IRI), as modified by Bugoni \& Vooren (2004) from PinKas et al. $(1971)$, where IRI $=(\mathrm{N} \%+\mathrm{M} \%) \cdot \mathrm{FO} \%$.

\section{RESULTS}

Abundance. The highest number of Little Blue Herons of the three plumage classes combined was recorded in March 2009 at the Marinheiros Island colony and in May 2009 at the Tamandaré roost. By adding up the highest numbers of individuals of each plumage class recorded at any time during the study period, the minimum population estimate obtained during that period was 53 individuals in the Marinheiros colony (34 adults in February 2009, plus seven intermediate and 12 juveniles in March 2009), and 49 individuals at the Tamandaré roost (42 adults and two juveniles in May 2009, plus five intermediate in July 2009). Thus, more adult herons were observed in the Tamandaré roost than in the breeding colony, and more juveniles were observed in the breeding colony than at the roosting site (Fig. 2).

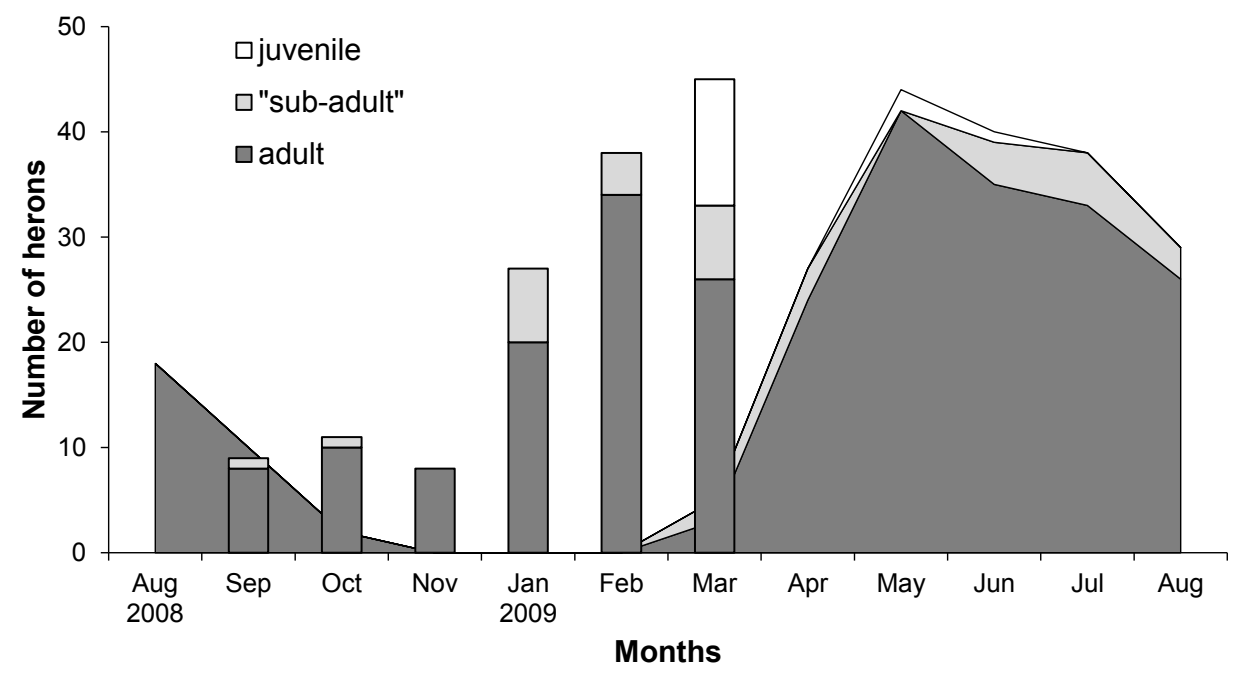

Fig. 2. Number of Little Blue Herons Egretta caerulea (Linnaeus, 1758) in different plumages recorded during sunset census in the colony of Marinheiros Island (bars) and in the roosting site of Tamandaré Park (area) from August 2008 to August 2009. 


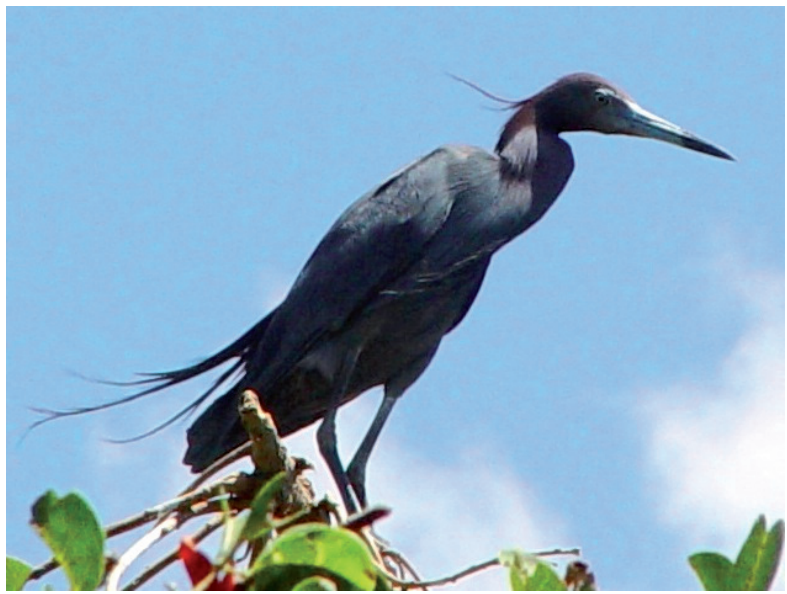

Fig. 3. Little Blue Heron Egretta caerulea (Linnaeus, 1758) in breeding plumage in the colony of Marinheiros Island.

Little Blue Herons were observed roosting at the Marinheiros colony exclusively from September to March, and during that period they were scarce or absent at the nocturnal roosting place in the city centre. At the colony, the birds in adult and intermediate plumages increased sharply in number in January, remained abundant until March, and disappeared in April. At the Tamandare roost the numbers of those birds sharply increased in April to values similar to the numbers of the previous months in the colony, and remained abundant until August. Birds in juvenile plumage appeared in the colony in March 2009 and occurred after that at the Tamandaré roost until June.

Breeding. The breeding cycle of Little Blue Herons in Patos Lagoon estuary began in September, when herons started to gather at the colony of Marinheiros Island in breeding plumage, evidenced by red-brown head and neck, and long lanceolate plumes on the back (Kushlan \& Hancock, 2005) (Fig. 3). Five Little Blue Heron nests were recorded, one in November 2008, two in January 2009, one in February 2009, and another in November 2009, amongst Snowy Egret and Cattle Egret nests. The end of the breeding cycle was characterized by the abandonment of the colony in late March/early April after all young fledged, and by the reoccupation of the Tamandare roost, which had been abandoned by the birds during the breeding season (Fig. 2).

Nests were found at heights varying from 1.5 to $4.3 \mathrm{~m}$ above ground, on four plant species (Tab. I; Figs $4,5)$. One nest was detected before egg laying, and was identified through the observation of an adult heron in the nest. Three nests were detected when they contained two nestlings of about ten days old. In one of these nests the third nestling was found dying on the ground below the nest. The other nest contained two eggs and one nestling of about ten days old (Fig. 5). The nestling that was found dying on the ground was collected after its death and deposited in the ornithological collection of the Museu de Ciências e Tecnologia da Pontifícia
Universidade Católica do Rio Grande do Sul - PUCRS (MCP 2662).

Food. In the 13 regurgitations that were collected, a total of 85 preys was found, 62 of which were Pink Shrimp Farfantepenaeus paulensis (Pérez-Farfante, 1967) (Peneidae), 15 bony fish (mostly Mullets Mugil sp., Mugilidae), and eight crabs. The estuarine food items, especially crustaceans, were the most important ones, representing $99 \%$ of the total food mass (Tab. II). All fish and most shrimp measured between 20 and $50 \mathrm{~mm}$ TL (Tab. III). Although shrimp was the most frequent and abundant food item, seven Blue Crabs Callinectes sapidus (Rathbun, 1897) (Portunidae) constituted $78 \%$ of the total food mass because of their larger size (Tabs II, III). All the crabs regurgitated by the herons were whole, with soft uncalcified carapace, which is evidence that they had recently molted.
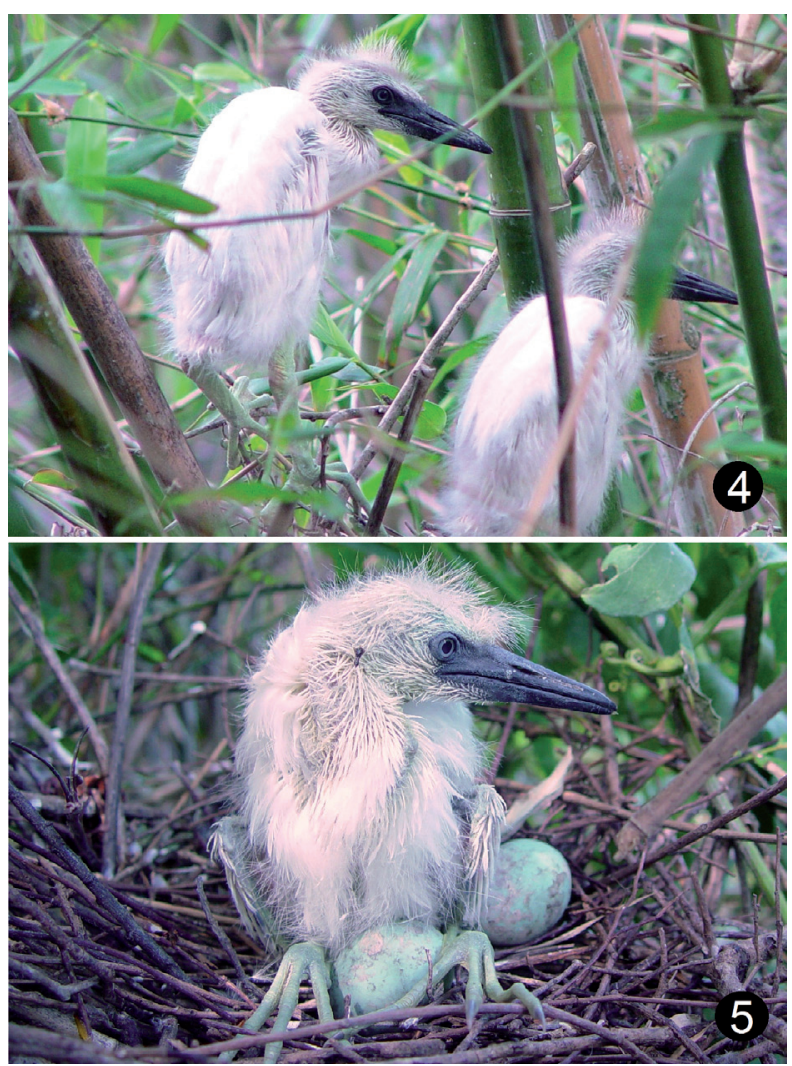

Figs 4, 5. Nestlings and eggs of Little Blue Heron Egretta caerulea (Linnaeus, 1758) in the colony of Marinheiros Island, Patos Lagoon estuary: 4 , nest $3 ; 5$, nest 4 , which was subsequently abandoned.

\section{DISCUSSION}

Range expansion. Although GianUCA et al. (2008) presented evidence of a southward range expansion of the Little Blue Heron, the breeding of the species within the Patos Lagoon estuary had not been confirmed so far. Thus, this study confirms expansion of the breeding range of this heron $400 \mathrm{~km}$ south of the limit of Neotropical mangroves (Cintrón-Molero \& SchaefFer-Novelli, 1992) and $850 \mathrm{~km}$ south of the nearest known breeding 
Tab. I. Aspects of the nesting biology of the Little Blue Heron Egretta caerulea (Linnaeus, 1758) in the colony of Marinheiros Island, Patos Lagoon estuary, state of Rio Grande do Sul, southern Brazil.

\begin{tabular}{|c|c|c|c|c|c|}
\hline Nest & Date of discovery & Vegetation & $\begin{array}{l}\text { Nest height } \\
\text { (m) }\end{array}$ & $\begin{array}{l}\text { Content at } \\
\text { discovery }\end{array}$ & Content at last check \\
\hline 1 & 16 Nov 2008 & $\begin{array}{c}\text { Daphnopsis } \\
\text { racemosa }\end{array}$ & 1.5 & 2 nestlings & 2 fledglings \\
\hline 2 & 24 Jan 2009 & $\begin{array}{l}\text { Sebastiana } \\
\text { brasiliensis }\end{array}$ & 4.2 & 3 eggs & 2 fledglings \\
\hline 3 & 24 Jan 2009 & Bambusa sp. & 2.9 & 2 nestlings $^{a}$ & 2 fledglings \\
\hline 4 & 3 Feb 2009 & Bambusa sp. & 2.1 & $\begin{array}{l}1 \text { nestling, } \\
2 \text { eggs }\end{array}$ & $\begin{array}{l}1 \text { dead nestling, } \\
2 \text { eggs }\end{array}$ \\
\hline 5 & 25 Nov 2009 & $\begin{array}{c}\text { Mimosa } \\
\text { bimucronata }\end{array}$ & 2.3 & 2 nestlings & not determined \\
\hline
\end{tabular}

${ }^{a}$ A third nestling was moribund on the ground under the nest.

${ }^{\mathrm{b}}$ The nest was abandoned.

Tab. II. Diet composition of the Little Blue Heron Egretta caerulea (Linnaeus, 1758) during the breeding season in the colony of Marinheiros Island, Patos Lagoon estuary, state of Rio Grande do Sul, southern Brazil: absolute and relative (\%); FO, frequency of occurrence; $\mathrm{N}$, contribution by number; $\mathrm{M}$, contribution by reconstructed mass; IRI, index of relative importance.

\begin{tabular}{lrrrrrrr}
\hline Food item & FO & FO $\%$ & N & N\% & M (g) & M\% & IRI \\
\hline Crustacea (Decapoda) & & & & & & & \\
$\quad$ Farfantepenaeus paulensis (Pérez-Farfante, 1967) & 8 & 61.5 & 62 & 72.9 & 36.9 & 16.6 & 5509.6 \\
$\quad$ Callinectes sapidus (Rathbun, 1896) & 6 & 46.2 & 7 & 8.2 & 173.1 & 77.9 & 3974.6 \\
$\quad$ Cyrtograpsus angulatus (Dana, 1851) & 1 & 7.7 & 1 & 1.2 & 2.0 & 0.9 & 15.8 \\
Bony fish & & & & & & & \\
$\quad$ Mugil sp. (Mugilidae) & 2 & 15.4 & 10 & 11.8 & 7.7 & 3.5 & 234.4 \\
$\quad$ Characidae & 1 & 7.7 & 5 & 5.9 & 2.6 & 1.2 & 54.2 \\
\hline Total & - & - & 85 & 100 & 222,3 & 100 & - \\
\hline
\end{tabular}

${ }^{a}$ Two Astyanax sp., two Cheirodon sp., one Hyphessobrycon sp. (freshwater fishes).

Tab. III. Mean and range (in parenthesis) of total length (TL) or carapace width (CW) and reconstituted mass of prey regurgitated by Little Blue Heron Egretta caerulea (Linnaeus, 1758) nestlings in the colony of Marinheiros Island, Patos Lagoon estuary, southern Brazil.

\begin{tabular}{lrrr}
\hline Food item & $\mathrm{n}$ & TL or CW $(\mathrm{mm})$ & Mass $(\mathrm{g})$ \\
\hline Crustacea (Decapoda) & & & \\
$\quad$ Farfantepenaeus paulensis (Pérez-Farfante, 1967) & 57 & $36.5(16-55)$ & $0.6(0.1-1.6)$ \\
Callinectes sapidus (Rathbun, 1896) & 5 & $50.6(48-86)$ & $30.6(10.6-66.4)$ \\
Cyrtograpsus angulatus (Dana, 1851) & 1 & 28 & 1.9 \\
Bony fish & & $34.9(29-48)$ & $0.8(0.2-1.7)$ \\
Mugil sp. (Mugilidae) & 10 & $35.2(23-47)$ & $0.6(0.1-1.5)$ \\
$\quad$ Characidae & 5 & & \\
\hline
\end{tabular}

sites, located at the Santos-Cubatão mangroves (OLmos \& Silva E SiLVA, 2002).

Temperature is one of the main limiting factors of the large-scale geographical distribution of birds, and low winter temperatures determine the distribution boundaries of several species at higher latitudes (Root, 1988a,b; MATTHEws et al., 2004). Increase in temperature due to climate changes is primarily responsible for recent geographic expansion of birds in Africa, Europe and North America (Thomas \& LenNon, 1999; MACCARTY, 2001; CRICK, 2004; PARMESAn, 2006). According to data from the "Brazilian Long Term Ecological Research Program" (LTER/CNPq), quoted by GiANUCA et al. (2008), the mean air temperature in the Patos Lagoon estuary in the last two decades increased by $3^{\circ} \mathrm{C}$ since the beginning of the $20^{\text {th }}$ century. Additionally, according 
to the same source, decadal frequency of months with mean air temperatures lower than $15^{\circ} \mathrm{C}$ has decreased from $35.0 \%$ in the 1900 s to $14.1 \%$ in the 2000 s, and during the last four decades the monthly mean air temperature has not fallen below $10^{\circ} \mathrm{C}$. As the distribution of the Little Blue Heron in the Northern Hemisphere is limited latitudinally by low temperatures (MATTHEWs et al., 2004), the recent colonization of the Patos Lagoon estuary by this species may have been favored by the climate warming documented in this region (GIANUCA et al., 2008). According to THOMAs et al. (2001), once an expansion is initiated, individuals and populations that expand more rapidly are likely to be favored, and expanding range fronts may become characterized by dispersive generalists or by specialists on habitats common in the area of expansion. This last circumstance appears to be the situation of the Little Blue Heron, which is one of the most dispersive of the Neotropical herons (KuSHLAN \& HANCOCK, 2005), and an estuary-specialist species in South America (SICK, 1997; Olmos \& Silva e Silva, 2002, 2003; Kushlan \& Hancock, 2005).

Although a warming of the climate recorded in the southern state of Rio Grande do Sul may have favored the recent colonization of the Patos Lagoon by the Little Blue Heron, other factors must be considered, as the degradation of southwest Atlantic estuaries during the last few decades (Cintrón-Molero \& SchaefferNovelli, 1992; Diegues, 1999; Olmos \& Silva e Silva, 2003), forcing birds to areas outside their normal range; or a possible population increase.

The Yellow-crowned Night Heron, another ardeid whose distribution is limited to the north by low temperatures (Matthews et al., 2004) and in South America is restricted to mangroves (Olmos \& Silva E Silva, 2003; Kushlan \& Hancock, 2005), also recently expanded southward to the Patos Lagoon estuary, breeding successfully $500 \mathrm{~km}$ south of its previously southernmost colony (GianucA, 2007), located at Florianópolis in the state of Santa Catarina (Gianuca et al., 2011). The expansion of the breeding range of these two herons appears to be more significant than that reported for 59 freshwater and terrestrial breeding bird species in Europe, with an average northward expansion of only $19 \mathrm{~km}$ attributed to climate warming (THOMAS \& LENNON, 1999).

Abundance. Probably most, if not all, Little Blue Herons that breed in the colony of Marinheiros Island roost at Tamandaré Park during the non-breeding period. Supporting evidence was the very similar values of abundance recorded at the colony and subsequently at the Tamandaré roost, as expected if the same population used exclusively both these places. Furthermore, there are no other breeding or nocturnal roosting sites of herons known in the vicinity of the Patos Lagoon estuary.

Some juvenile Little Blue Herons may disperse to other areas, abandoning the estuary. This behavior is common during the first year of herons in general (Olrog, 1975; Erwin et al., 1996), and could explain the low number of juveniles observed at the nocturnal roosting site compared with the number observed in the colony. The discrepancy between the number of Little Blue Herons recorded at the breeding colony and the number of nests actually found is probably a result of difficulties in detecting the few nests of this species among about 1,800 nests of the Snowy Egret and Cattle Egret, which were virtually identical to the Little Blue Heron nests. According to Maxwell \& Kale (1977), the identification of nests of Egretta herons and Cattle Egrets is difficult before nestlings reach an age of 5 days. Food. Although the diet of the Little Blue Heron is diverse, including fish, amphibians, crustaceans, and insects, the proportions of prey items differ among regions, and in some areas it appears to be a specialist in one or a few food recourses (KUSHLAN \& HANCOCK, 2005). A preliminary analysis of food during the breeding season suggests that the Little Blue Herons in the Patos Lagoon estuary feed their young mainly with crustaceans, as they do in mangrove areas (MIRANDA \& Collazo, 1997; Olmos et al., 2001; Olmos \& Silva E SILVA, 2003). However, in this study, small shrimps were found to be the most frequent and abundant prey, while in the mangroves of the state of São Paulo crabs were most abundant (between $75 \%$ to $85 \%$ of prey), especially the semi-terrestrial species Aratus pisoni $(\mathrm{H}$. Milne Edwards, 1837) and Armases rubriceps (Rathbun, 1897) (Olmos et al., 2001; Olmos \& Silva e Silva, 2003). None of the prey detected in the present study can be found out of water, evidencing that in the Patos Lagoon estuary Little Blue Herons forage mainly on submerged estuarine substrates, instead of on exposed mudflats as observed in mangrove areas (Olmos et al., 2001; Olmos $\&$ Silva E SiLva, 2003). On the other hand, our results are in agreement with OLmos et al. (2001) in that the Little Blue Herons select crabs with recently molted, soft carapaces, similar to the way in which Snowy Egrets prey upon crayfish Procambarus sp. in Louisiana (USA) (KING \& LeBlanc, 1995).

In conclusion, according to our findings and the observations of GiANUCA et al. (2008), a population of Little Blue Herons composed by about 50 individuals is established on the Patos Lagoon estuary at least since 2007. Despite the absence of mangroves in this region, Little Blue Herons found appropriate habitat for roosting and breeding, distant $6 \mathrm{~km}$ from each other, among very suitable estuarine foraging areas in which they prey mainly on crustaceans in shallow water.

Acknowledgements. We would like to thank Abilio dos Santos Ruas and Robeli Rodrigues Correia for allowing us to camp on their properties during the field work on the Marinheiros Island, Dinarte Martins for authorized access to the colony on private land under his care, and Cláudia Giongo and Ubiratã Soares Jacobi for help in the plant identifications. Fabiano Corrêa and Felipe Cestari Dumont helped identify fishes and crustaceans, respectively. We are also grateful to Samantha Regina Klein for help during the diet analyses and to Rafael A. Dias for the transport of the Little Blue Heron nestling to PUCRS's ornithological collection at Porto Alegre. Eric Hoddy reviewed the English version. 


\section{REFERENCES}

Alaniz, M. R. 2009. Crescimento e ciclo de mudas de Callinectes sapidus (Rathbun, 1896) no estuário da Lagoa dos Patos. M.Sc. Thesis. Universidade Federal do Rio Grande, Rio Grande.

Asmus, M. L. 1997. Coastal plain and Patos Lagoon. In: SEeliger, U.; Odebrecht, C. \& Castello, J. P. eds. Subtropical Convergence environments. Berlin, Springer-Verlag. p.9-11.

Bemvenuti, C. E. 1997. Benthic invertebrates. In: Seeliger, U.; Odebrecht, C. \& Castello, J. P. eds. Subtropical Convergence environments. Berlin, Springer-Verlag. p.40-43.

Bugoni, L. \& Vooren, C. M. 2004. Feeding ecology of Common Tern Sterna hirundo in a wintering area in southern Brazil. Ibis 146:438-453.

Cintrón-Molero, G. \& Schaeffer-Novelli, Y. 1992. Ecology and management of New World mangroves. In: SeELiger, U. ed. Coastal plant communities of Latin America. San Diego, Academic Press. p.233-258.

Costa, C. S. B. 1997. Tidal marshes and wetlands. In: SeEliger, U.; Odebrecht, C. \& Castello, J. P. eds. Subtropical Convergence environments. Berlin, Springer-Verlag. p.24-26.

Costa, C. S. B.; Seeliger, U. \& Kinas, P. G. 1988. The effect of wind velocity and direction on the salinity regime in the lower Patos Lagoon estuary. Ciência e Cultura 40:909-912.

CRICK, H. Q. P. 2004. The impact of climate change on birds. Ibis 146:48-56.

Diegues, A. C. 1999. Human populations and coastal wetlands: conservation and management in Brazil. Ocean and Coastal Management 42:187-210.

D’Incao, F. \& Calazans, D. 1978. Relações biométricas do “camarão rosa" Penaeus paulensis Pérez Farfante, 1967 na Lagoa dos Patos, RS, Brasil. Atlântica 3:57-66.

Erwin, R. M.; Haig, J. G.; Stotts, D. B. \& Hatfield, J. S.1996. Dispersal and habitat use by post-fledging juvenile Snowy Egrets and Black-crowned Nigth Herons. Willson Bulletin 10:342-356.

Fischer, L. G.; Pereira, L. E. D. \& Vieira, J. P. 2004. Peixes estuarinos e costeiros. 1 ed. Rio Grande, Ecoscientia. 128p.

GianucA, D. 2007. Ocorrência sazonal e reprodução do socócaranguejeiro Nyctanassa violacea no estuário da Lagoa dos Patos, novo limite sul da sua distribuição geográfica. Revista Brasileira de Ornitologia 15:464-467.

Gianuca, D.; Branco, J. O. \& Vooren, C. M. 2011. Notes on the reproduction of Yellow-crowned Night Heron in southern Brazil. Cotinga 33:63-72.

Gianuca, D.; Quintela, F. M.; Barros, J. A.; Gomes, A. \& Gianuca, N. M. 2008. Ocorrência regular da garça-azul Egretta caerulea (Ciconiiformes, Ardeidae) no estuário da Lagoa dos Patos, Rio Grande do Sul, Brasil. Pan-American Journal of Aquatic Sciences 3:328-334.

Haimovici, M. \& Velasco, G. 2000. Length-weigth relationship of marine fish from southern Brazil. Naga 23:19-23.

Isacch, J. P.; Costa, C. S. B.; Rodríguez-Gallego, R.; Conde, D.; Escapa, M.; Gagliardine, D. A. \& Iribarne, O. 2006. Distribution of saltmarsh plant communities associated with environmental factors along a latitudinal gradient on the south-west Atlantic coast. Journal of Biogeography 33:888-900.

KING, D. T. \& LEBlanC, D. 1995. Foraging behavior of Snowy Egrets (Egretta thula) and Yellow-crowned Night Herons (Nyctanassa violacea) in South Louisiana. Colonial Waterbirds 18:224-225.

Kushlan, J. A. \& Hancock , J. A. 2005. The herons. Oxford, Oxford Academic Press. 433p.

MacCarty, J. P. 2001. Ecological effects of recent climate change. Conservation Biology 15:320-331.

Matthews, S.; O’Connor, R.; Inverson, L. R. \& Prasad, A. M. 2004. Atlas of climate change effects in 150 bird species of the eastern United States. Gen. Tech. Rep. NE-318. Newtown Square, PA:
U.S. Department of Agriculture, Forest Service, Northeastern Research Station. 340p. Available in: < http://sbisrvntweb.uqac.ca/ archivage/18371270.pdf $>$. Accessed on: 03.01.2011.

Maurício, G. N. \& Dias, R. A. 1996. Novos registros e extensões de distribuição de aves palustres e costeiras no litoral do Rio Grande do Sul. Ararajuba 4:47-51.

. 2000. New distribution information for birds in Southern Rio Grande do Sul, Brazil, and the first record of the Rufous Gnateater Conopophaga lineatta for Uruguay. Bulletin of the British Ornithologists' Club 120:230-237.

Maxwell, G. R. \& Kale, H. W. 1977. Breeding biology of five species of herons in coastal Florida. Auk 94:689-700.

Miranda, L. \& Collazo, J. A. 1997. Food habits of four species of wading birds (Ardeidae) in a tropical mangrove swamp. Colonial Waterbirds 20:413-418.

MoHr, L. V. 2003. Primeiro registro documentado da garça-azul Egretta caerulea no Rio Grande do Sul. Atualidades Ornitológicas 116:2-3.

Narosky, T. \& Yzurieta, D. 1993. Guía para la identificación de las aves de Argentina y Uruguay. 4 ed. Buenos Aires, Vasquez Manzini. 337p.

Olmos, F. \& Silva e Silva, R. 2002. Breeding biology of Litle Blue Heron (Egretta caerulea) in southeastern Brazil. Ornitologia Neotropical 13:17-30.

2003. Guará: ambiente, fauna e flora dos manguezais de Santos-Cubatão. São Paulo, Empresa das Artes. 215p.

Olmos, F.; Silva E Silva, R. \& Prado, A. 2001. Breeding season diet of Scarlet Ibises and Little Blue Herons in a Brazilian mangrove swamp. Waterbirds 24:50-57.

Olrog, C. C. 1975. Vagrancy of Neotropical Cormorant, egrets and White-Faced Ibis. Bird Banding 46:207-212.

Parmesan, C. 2006. Ecological and evolutionary responses to recent climate change. Annual Review of Ecology, Evolution, and Systematics 37:637-669.

Pinkas, L.; Oliphant, M. S. \& Iverson, I. L. 1971. Food habitat of Albacore, Bluefin Tuna, and Bonito in California waters. Fisheries Bulletin 152:1-105.

Root, T. 1988a. Energy constraints on avian distribution and abundance. Ecology 69:330-339.

1988b. Environmental factors associated with avian distribution boundaries. Journal of Biogeography 15:489-505.

SeEliger, U. 1997a. Benthic Macroalgae. In: Seeliger, U.; Odebrecht, C. \& Castello, J. P. eds. Subtropical Convergence Environments. Berlin, Springer-Verlag. p. 27-30.

1997b. Submerse Spermatophytes. In: SeEliger, U.; Odebrecht, C. \& Castello, J. P. eds. Subtropical Convergence Environments. Berlin, Springer-Verlag. p. 24-27.

Sick, H. 1997. Ornitologia brasileira. Rio de Janeiro, Nova Fronteira. $912 \mathrm{p}$.

Thomas, D. C. \& Lennon, J. J. 1999. Birds extend their ranges northwards. Nature 399: 213.

Thomas, C. D.; Bodsworth, T. J.; Wilson, R. J.; Simmons A. D.; Davies Z. G.; Musche, M. \& Conradt, L. 2001. Ecological and evolutionary processes at expanding range margins. Nature 441:577-581.

ViannA, M. \& D'IncAo, F. 2006. Evaluation of by-catch reduction devices for use in the artisanal pink shrimp (Farfantepenaeus paulensis) fishery in Patos Lagoon, Brazil. Fisheries Research 81:331-336.

Voss, W. A. 1984. Comunicação sobre a ocorrência da garça-morena, Florida caerulea (Linnaeus, 1758), no Rio Grande do Sul. Acta Biologica Leopoldensia 6(2):247-248.

Votto, A.; Gomes Jr, A.; Bugoni, L. \& Pereira JR, J. 2006. Sazonalidade da avifauna no campus Carreiros da Fundação Universidade Federal de Rio Grande, Rio Grande do Sul, Brasil. Estudos de Biologia 28:45-55. 